\title{
A háromdimenziós power Doppler-indexek és a perinatalis kimenetel vizsgálata méhen belüli növekedési restrikcióval szövődött terhességekben
}

\author{
Molnár András dr. ${ }^{1}$. Surányi Andrea dr. ${ }^{1}$ - Jakó Mária dr. ${ }^{1}$ \\ Nyári Tibor dr. ${ }^{2}$ - Németh Gábor dr. ${ }^{1}$ \\ Szegedi Tudományegyetem, 'Általános Orvostudományi Kar, Szülészeti és Nőgyógyászati Klinika, \\ ${ }^{2}$ Orvosi Fizika és Informatikai Tanszék, Szeged
}

\begin{abstract}
Bevezetés: A méhen belüli növekedési restrikció (IUGR) kialakulása az esetek egy részében anyai vagy magzati okokra és számos esetben lepényi okokra (csökkent lepényi keringés) vezethető vissza.

Célkitüzés: Célkitüzésünk a csökkent lepényi erezettség/keringés és a császármetszésarány, illetve a klinikai kimenetel közötti összefüggés vizsgálata volt, továbbá megfelelően hitelesített és reprodukálható módszer használata a placenta in vivo funkcionális vizsgálatára, amely késóbb a rutin-terhesgondozásba is beépíthetó.

Módszer: Prospektív eset-kontroll vizsgálatunkba 254, második és harmadik trimeszterben lévő várandóst vontunk be, akiknél vascularisatiós indexet (VI), áramlási indexet (FI) és vascularisatiós áramlási indexet (VFI) mértünk 3 dimenziós power Doppler- (3DPD) technikával.

Eredmények: A VI-középérték $3,7 \%(3,2 \%-4,2 \%)$ volt az IUGR- és $10,1 \%(8,6 \%-10,9 \%)$ a kontrollcsoportban $(\mathrm{p}=0,001)$. Az FI középértéke 40,0 $(39,7-42,5)$ volt az IUGR- és 45,1 $(44,1-53,1)$ a kontrollcsoportban $(\mathrm{p}=0,012)$. A VFI esetén ezeket az értékeket 2,2-nek $(2,1-2,4)$ és 4,8-nek $(4,4-5,3)(\mathrm{p}=0,001)$ mértük.

Köpetkeztetések: A 3DPD-indexek alkalmasak lehetnek az IUGR-terhességek kiszürésére, a kórkép hátterében lévő megváltozott keringés vizsgálatára.
\end{abstract}

Orv Hetil. 2017; 158(26): 1008-1013.

Kulcsszavak: méhen belüli növekedésbeli restrikció, perinatalis klinikai kép, méhlepény-vascularisatio, testtömegindex, terhesgondozás, háromdimenziós power Doppler-ultrahang

Examination of placental three-dimensional power Doppler indices and perinatal outcome in pregnancies complicated by intrauterine growth restriction

Introduction: Development of intrauterine growth restriction (IUGR) can be traced back to maternal or fetal factors, but in many cases we find placental factors (reduced placental circulation) in the background.

Aim: Our aim was to examine whether the reduced placental bloodperfusion and vascularity show any correlation with cesarean section frequency and the clinical outcome in IUGR pregnancies. The aim of the present study was also to use a properly calibrated and reproducible method for evaluating placental blood flow, that can later be incorporated into the routine examination.

Method: 254 women were recruited in our prospective case-control study. The 3 dimensional power Doppler (3DPD) ultrasound indices; vascularisation index (VI), flow index (FI) and vascularization flow index (VFI) were measured on each participant.

Results: Median VI was 3.7\% (interquartile range [IQR] 3.2\%-4.2\%) in the IUGR group and $10.1 \%$ (IQR 8.6\%$10.9 \%$ ) in the control group ( $\mathrm{p}=0.001$ ). Median FI value was 40.0 (IQR 39.7-42.5) in the IUGR group and 45.1 (IQR 44.1-53.1) in the control group $(\mathrm{p}=0.012)$. Median VFI was $2.2($ IQR 2.1-2.4) in the IUGR group and 4.8 (IQR 4.4-5.3) in the control. 
Conclusions: The 3DPD indices may be useful for examining changes in circulation in IUGR pregnancies to characterize the underlying pathology.

Keywords: intrauterine growth restriction, perinatal outcome, placental vascularization, body mass index, pregnancy care, three-dimensional power Doppler indices, ultrasonography

Molnár A, Surányi A, Jakó M, Nyári T, Németh G. [Examination of placental three-dimensional power Doppler indices and perinatal outcome in pregnancies complicated by intrauterine growth restriction]. Orv Hetil. 2017; 158(26): 1008-1013.

(Beérkezett: 2017. április 12.; elfogadva: 2017. május 10.)

\begin{abstract}
Rövidítések
3DPD = (3-dimensional power Doppler) háromdimenziós power Doppler-index; BMI = (body mass index $)$ testtömegindex; $\mathrm{FI}=($ flow index $)$ áramlási index; HIV = human immunodeficiency vírus; IUGR = (intrauterine growth restriction) méhen belüli növekedésbeli visszamaradás; $\mathrm{IQR}=$ (interquartile range) interkvantilis tartomány; NT = (nuchal translucency) tarkóredő-vastagság; SPSS = Statistical Package for Social Science; $\mathrm{VI}=($ vascularisation index $)$ vascularisatiós index; VFI = (vascularization flow index) vascularisatiós áramlási index; VOCAL $=$ virtual organ computer-aided analysis
\end{abstract}

A foetoplacentalis keringés megváltozása a méhlepény és a magzat fejlődésének visszamaradásával járhat. Az egyik ilyen súlyos szövődményről, a méhen belüli növekedési restrikcióról (IUGR) akkor beszélünk, amikor a magzat becsült súlya az adott terhességi korra számolt 10. percentilis alatt van $[1,2]$. Az IUGR hátterében csökkent lepényi keringés, magzati fejlődési rendellenesség is állhat, de okozhatják anyai betegségek is. Klinikai megnyilvánulása elsősorban attól függ, hogy a kiváltó tényező milyen időtartamban éri a magzatot [3]. Munkánk során az etiológiai tényezők közül a csökkent lepényi keringést vizsgáltuk. Különböző módszerek ismertek a placenta ereinek in vivo áramlási értékeinek mérésére: de Paula és $m t s a i[4]$ a méhlepény teljes térfogatát vizsgálták virtual organ computer-aided analysis (VOCAL-) technikával, de ez a módszer nem használható a terhesség késői szakaszában, amikor a lepényi eredetû́ IUGR manifesztálódik. Guiot és mtsai [5] öt különböző helyen határozták meg a háromdimenziós power Doppler-indexeket (3DPD) a lepényben. Noguchi és mtsai [6] 9-12 gömb alakú minta alapján számoltak átlag vascularisatiós értéket a teljes méhlepényre (Noguchi-féle placenta-szonobiopszia). Azonban sem a mintavételi térfogat, sem a mintavételi helyek száma nem volt standardizálva. Az átlagérték számításakor az adatok közé kerültek a lepény széléről származó, erekben szegény és a lepény centrális részéről származó, jól vascularizált minták is, amelyek tetszőleges aránya már jelentős mértékben befolyásolhatta a kapott eredményeket. A Mercé-féle szonobiopsziát alkalmaztuk a jelen vizsgálatban, mert ez a módszer már jól definiált és validált, és jellemző az alacsony intra- obszerver és interobszerver hiba [7, 8]. Mercé szerint [7] a köldökzsinór eredésénél vizsgált $3 \times 3 \times 3 \mathrm{~mm}^{3}$ térfogatú szövetrész a méhlepény legjobban vascularizált része. Ez a módszer nemcsak a terhesség első harmadában használható, amikor a lehetséges szövődmény túlnyomó többsége még nem észlelhetô, hanem a második és harmadik trimeszterben is. Korábban Guimarães Filho és mtsai 283 várandóson [9], 26-35 terhességi héten vizsgálták a három index változását a lepény elhelyezkedésének függvényében. Kimutatták, hogy a méhlepény elhelyezkedésének nincs jelentős hatása a 3DPD-indexek értékeire, viszont nem vizsgálták a placentatapadási anomáliákat és a morfológiai rendellenességeket, ezért az ilyen eseteket ki kellett zárnunk, mivel ezek befolyásolhatják a keringést a terhesség elejétől [10] és ez torzítaná az eredményeket.

Célul tűztük ki annak vizsgálatát, hogy a csökkent lepényi keringés és erezettség - amely IUGR-terhességekben gyakori - összefüggést mutat-e a császármetszés gyakoriságával és a klinikai kimenetellel. Vizsgáltuk, hogy a graviditás, paritás és az anyai testtömegindex miként befolyásolja a méhlepény áramlását jellemző 3DPDindexeket, illetve, hogy a csökkent lepényi keringés milyen kapcsolatban van a perinatalis klinikai képpel IUGR- és normális terhességek esetén. Jelen tanulmány célja továbbá az volt, hogy egy megfelelően hitelesített és reprodukálható módszert használjunk a placenta in vivo funkcionális vizsgálatára, amely később a kockázattal rendelkező terhesek vizsgálatába is beépíthető.

\section{Módszer}

A Szegedi Tudományegyetem Szülészeti és Nőgyógyászati Klinikáján 2012 és 2016 között a 135/2011 számú etikai engedély alapján végzett prospektív eset-kontroll vizsgálatunkba 254, második és harmadik trimeszterben lévő várandóst vontunk be. A rekrutáció során az alábbi esetek kizárásra kerültek: többes terhesség, megvastago$\operatorname{dott}(\mathrm{NT} \geq 3 \mathrm{~mm})$ tarkóredő a 11 . és a 13. terhességi hét között mérve, strukturális vagy kromoszóma-rendellenesség, kábítószer-használat, alkoholfogyasztás, koffeinvagy nikotinbevitel és a terhességet befolyásoló szisztémás betegség (például autoimmun betegség, vasculitis, 


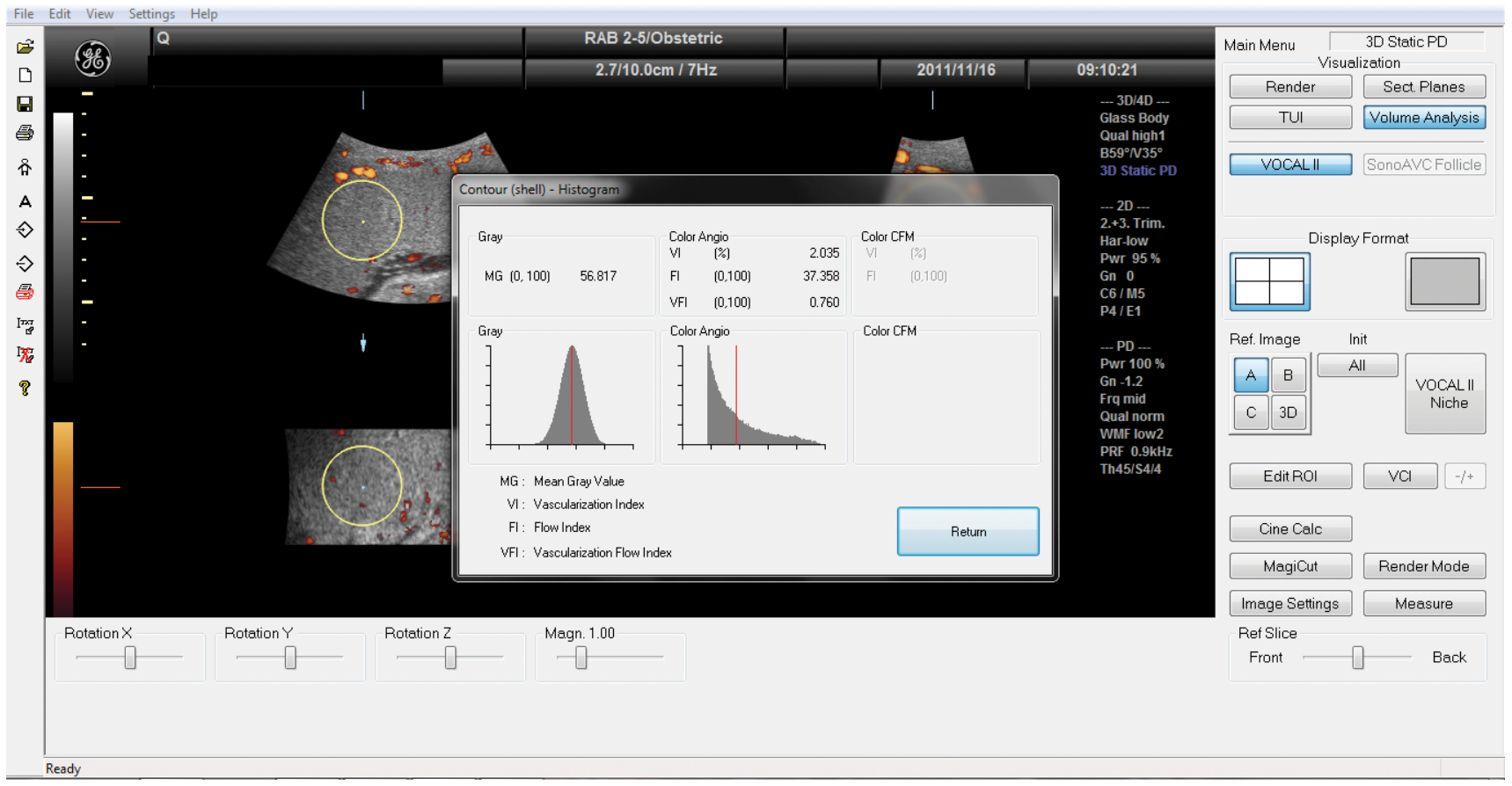

1. ábra

Mercé-féle szonobiopszia [7] és a méhlepény háromdimenziós power Doppler-indexei. A kör megfelel a Mercé által előírt mintavételnek; 28 ml-es lepénytérfogat közvetlenül a köldökzsinór tapadásánál

haemophilia, thrombophilia, cukorbetegség, a keringési rendszer betegségei, HIV-fertőzés) [11]. A második és harmadik trimeszterben végzett rutin-ultrahangvizsgálaton való megjelenés során azokat vontuk be vizsgálatainkba, akik a kizárási kritériumok értékelése alapján megfelelő esetnek bizonyultak: egyes terhesség és a fentiekben felsorolt állapotok hiánya.

A Helsinki Nyilatkozatnak megfelelően a vizsgálatokhoz minden résztvevő írásos beleegyezését adta. A résztvevőket a második trimeszterben végzett rutin-biometria során a Hadlock B formula [12] alapján becsült magzati súly szerint két csoportra osztottuk: normális terhesség (kontrollcsoport) és IUGR-csoport [2]. Meghatároztuk a három 3DPD-indexet a placentaperfúzió értékelésére $[6,7]$ : vascularisatiós indexet (VI), áramlási indexet (FI) és a vascularisatiós áramlási indexet (VFI). A VI a színes voxelek aránya az összes voxelhez képest, ez megfelel a vizsgált térfogaton belül az erek térfogatarányának (erezettség). Az FI az intenzitássúlyozott színes voxelek aránya az összes színes voxelhez képest, ami mutatja a vér áramlásának átlagos relatív mennyiségét (véráramlás). A VFI az intenzitássúlyozott színes voxelek aránya az öszszes voxelhez képest, az arányszám tükrözi az erek számát és a rajtuk átáramló vér mennyiségét is. Mindhárom index értéktartománya 0-100 [7]. A két- és háromdimenziós, illetve a power Doppler-vizsgálatot ugyanazon a napon végeztük Voluson 730 (GE Healthcare, Zipf, Ausztria) ultrahangkészülék RAB2-5 (2-5 MHz) konvex vizsgálófeje segítségével. A placenta vascularisatiójának megítélésére a Mercé által leírt szonobiopsziás módszert használtuk (1.ábra) [7]. A vizsgálati eredményeket a 3D ultrahangtechnikában jártas szakember elemezte
(S. A.) a VOCAL program 4D View 10.4 (GE Healthcare, Zipf, Ausztria) használatával. A klinikai adatok közül az újszülött adatait (köldökzsinór-artériás pH, egyperces, ötperces, tízperces Apgar-érték, születési súly és születési hossz) összehasonlítottuk a különböző kockázati tényezőkkel (csökkent lepényi vérellátás [VI, FI és VFI], anyai életkor, pregesztációs testtömegindex [BMI], a terhesség alatti túlzott súlygyarapodás és a szülés módja) rendelkező és nem rendelkező nők között. Az SPSS for Windows version 17.0 (SPSS Inc., Chicago, IL, Amerikai Egyesült Államok) program használatával végeztünk varianciaanalízist, hogy vizsgáljuk a 3DPD-indexek terhességgel, paritással és pregesztációs BMI-vel való összefüggését. A Mann-Whitney-féle U-tesztet, a t-próbát és a z-score-t használtuk arra, hogy összevessük a 3DPD-indexeket (VI, FI, VFI) a becsült magzati súlylyal, a születési súllyal és születési hosszal, a szülés módjával, a méhen belüli szövődmények előfordulásával, az újszülött intenzív osztályra szállításának szükségességével. A p $\leq 0,01$ értéket tekintettük statisztikailag szignifikánsnak. A 3DPD-indexek a terhesség, a paritás és a terhesség előtti BMI-vel való kapcsolatának vizsgálatára kvantilis regressziós módszert alkalmaztunk.

\section{Eredmények}

A becsült magzati súly átlagos z-score-értéke a 30 . és a 38. hét közötti IUGR-terhességek esetén -2,9 volt, tehát a becsült magzati súlyok az IUGR-csoportban a kontrollcsoportban mért átlagérték alatt voltak, a szórás közel háromszorosával. A bevont 254 terhesből 171 tarto- 
1. táblázat |A terhesség jellemzői

\begin{tabular}{|c|c|c|c|}
\hline & $\begin{array}{l}\text { Kontrollcsoport } \\
(\mathrm{n}=171)\end{array}$ & $\begin{array}{l}\text { IUGR-csoport } \\
(\mathrm{n}=83)\end{array}$ & $\mathrm{p}$ \\
\hline $\begin{array}{l}\text { Anyai életkor } \\
\text { (év, minimum-maximum) }\end{array}$ & $31,0(28-34)$ & $30,6(26-34)$ & 0,1 \\
\hline $\begin{array}{l}\text { 3DPD-indexek mérési } \\
\text { ideje terhességi kor } \\
\text { szerint (hét, minimum- } \\
\text { maximum) }\end{array}$ & $\begin{array}{l}30,4 \\
(19,0-37,0)\end{array}$ & $\begin{array}{l}32,1 \\
(24,1-37,6)\end{array}$ & 0,1 \\
\hline $\begin{array}{l}\text { Terhességi kor szüléskor } \\
\text { (hét, minimum- } \\
\text { maximum) }\end{array}$ & $\begin{array}{l}39,1 \\
(38,1-40,0)\end{array}$ & $\begin{array}{l}37,9 \\
(37,3-39,1\end{array}$ & 0,2 \\
\hline \multicolumn{4}{|l|}{ Előző terhességek száma } \\
\hline$<3$ & $123(71,9)$ & $35(42,2)$ & 0,01 \\
\hline$\geq 3$ & $48(28,1)$ & $48(57,8)$ & 0,01 \\
\hline \multicolumn{4}{|l|}{ Előző szülések száma } \\
\hline$<3$ & $87(83,7)$ & $33(39,8)$ & 0,01 \\
\hline$\geq 3$ & $17(16,3)$ & $32(38,6)$ & 0,01 \\
\hline Terhesség előtti BMI & $22,1 \pm 2,5$ & $22,1 \pm 1,7$ & 0,02 \\
\hline Perinatalis komplikációk & $12(7,0)$ & $13(15,7)$ & 0,01 \\
\hline $\begin{array}{l}\text { Intenzív újszülöttellátás } \\
\text { volt szükséges }\end{array}$ & $13(7,6)$ & $18(21,7)$ & 0,01 \\
\hline Császármetszés aránya & $45(26,3)$ & $31(37,3)$ & 0,01 \\
\hline \multicolumn{4}{|l|}{ Apgar-érték } \\
\hline Egyperces & $8,9 \pm 2,3$ & $9,0 \pm 1,4$ & 0,12 \\
\hline Ötperces & $9,3 \pm 1,3$ & $9,7 \pm 0,9$ & 0,01 \\
\hline Tízperces & $9,5 \pm 0,8$ & $9,8 \pm 1,0$ & 0,01 \\
\hline Születési hossz (cm) & $49,6 \pm 2,45$ & $45,7 \pm 3,3$ & 0,01 \\
\hline Születési súly (g) & $3351,9 \pm 522,4$ & $2662,8 \pm 744,3$ & 0,01 \\
\hline Köldökzsinór pH-értéke & $7,2 \pm 0,2$ & $6,9 \pm 1,4$ & 0,01 \\
\hline \multicolumn{4}{|l|}{ Lepény fekvése } \\
\hline Mellső fali & $97(56,7)$ & $46(55,4)$ & 0,23 \\
\hline Hátsó fali & $74(43,3)$ & $37(44,6)$ & 0,23 \\
\hline
\end{tabular}

2. táblázat $\mid$ Háromdimenziós power Doppler-indexek az IUGR- $(\mathrm{n}=83)$ és kontroll- $(\mathrm{n}=171)$ csoportban

\begin{tabular}{|c|c|c|c|c|c|c|c|}
\hline & \multicolumn{3}{|l|}{ IUGR } & \multicolumn{3}{|l|}{ Kontroll } & \multirow[t]{2}{*}{$\mathrm{p}$} \\
\hline & Medián & $\begin{array}{l}\text { Inter- } \\
\text { kvantilis } \\
\text { tarto- } \\
\text { mány }\end{array}$ & $\begin{array}{l}\text { Felső } \\
\text { és alsó } \\
\text { kiugró } \\
\text { értékek }\end{array}$ & Medián & $\begin{array}{l}\text { Inter- } \\
\text { kvantilis } \\
\text { tarto- } \\
\text { mány }\end{array}$ & $\begin{array}{l}\text { Felső } \\
\text { és alsó } \\
\text { kiugró } \\
\text { értékek }\end{array}$ & \\
\hline $\begin{array}{l}\text { VI } \\
(\%)\end{array}$ & 3,7 & $\begin{array}{l}3,2- \\
4,2\end{array}$ & $\begin{array}{l}0,6- \\
13,8\end{array}$ & 10,1 & $\begin{array}{l}8,6- \\
10,9\end{array}$ & $\begin{array}{l}6,8- \\
15,0\end{array}$ & 0,001 \\
\hline FI & 40,0 & $\begin{array}{l}39,7- \\
42,5\end{array}$ & $\begin{array}{l}28,0- \\
49,0\end{array}$ & 45,1 & $\begin{array}{l}44,1- \\
53,1\end{array}$ & $\begin{array}{l}33,0- \\
58,0\end{array}$ & 0,012 \\
\hline VFI & 2,2 & $\begin{array}{l}2,1- \\
2,4\end{array}$ & $\begin{array}{l}1,1- \\
4,1\end{array}$ & 4,8 & $\begin{array}{l}4,4- \\
5,3\end{array}$ & $\begin{array}{l}3,8- \\
6,1\end{array}$ & 0,0001 \\
\hline
\end{tabular}

IUGR = intrauterin növekedési visszamaradás; VI = vascularisatiós index; FI = áramlási index; VFI = vascularisatiós áramlási index zott a kontrollcsoportba és 83 az IUGR-csoportba. Az anyai életkor, a terhesség előtti BMI, a vizsgálat idején betöltött terhességi hetek száma, a szüléskor betöltött terhességi hetek száma, a lepény lokalizációja és az egyperces Apgar-érték nem különbözött szignifikánsan a csoportok között. Az előző terhességek és szülések száma, a köldökzsinór-artéria pH-ja és az ötperces és tízperces Apgar-érték viszont szignifikáns eltérést mutatott (1. táblázat). A császármetszés aránya szignifikánsan magasabb volt az IUGR-terhesség esetén, mint a kontrollcsoportban. Az IUGR-csoportban szignifikánsan alacsonyabb VI-, FI- és VFI-értékeket mértünk (2. táblázat). Az indexeket súlypercentilisre bontva a 3. táblázat tartalmazza. Az előző terhességek és szülések száma és a terhesség előtti BMI nem volt jelentős hatással a VI-re, FIre vagy VFI-re $(p>0,01)$, de szignifikáns különbség volt a VI, FI és VFI értékeiben a kontroll- és IUGR-csoport között $(\mathrm{p}<0,01)$. A perinatalis szövődmények az IUGRcsoportban $13(15,7 \%)$ újszülöttnél, a kontrollcsoportban $12(7,0 \%)$ újszülöttnél fordult elő $(\mathrm{p}=0,01)$. Az újszülött intenzív osztályon való ápolására volt szükség $18(21,7 \%)$ esetben az IUGR- és $13(7,6 \%)$ esetben a kontrollcsoportban $(\mathrm{p}=0,01)$. A terhességi kor mediánja 37,9 hét (interkvartilis tartomány 37,3-39,1) volt az esetcsoportban és 39,1 hét (interkvartilis tartomány $38,1-40,0 ; \mathrm{p}=0,2)$ a kontrollcsoportban. Az átlagos születési súly $2662,8 \pm 744,3 \mathrm{~g}$ volt az esetcsoportban és $3351,9 \pm 522,4 \mathrm{~g}$ a kontrollcsoportban $(\mathrm{p}=0,01)$, míg az átlagos születési hossz $45,7 \pm 3,3 \mathrm{~cm}$ volt az eset- és $49,6 \pm 2,45 \mathrm{~cm}$ a kontrollcsoportban $(\mathrm{p}=0,01)$.

\section{Megbeszélés}

A jelen prospektív vizsgálat a placenta vascularisatiós indexeinek meghatározását, ezáltal in vivo funkcionális vizsgálatát tűzte ki célul a Mercé-féle szonobiopszia segítségével [7]. Kimutatta, hogy a placentavascularisatio csökkent IUGR-terhességek esetén a normális terhességekhez képest már a második trimeszterben, megerősítve a korábbi eredményeket $[5,6]$. A lepény teljes erezettségének csökkenése, a fejletlen méhlepény elégtelen villusvérkeringéssel prediktív jele az IUGR kialakulásának akkor is, ha az arteria uterina és arteria umbilicalis áramlási értékei a normáltartományban vannak [13]. Azonban,

\begin{tabular}{lllll} 
3. táblázat & \multicolumn{4}{l}{$\begin{array}{l}\text { Percentilis értékek és háromdimenziós vascularisatiós indexek } \\
\text { kapcsolata méhen belüli növekedési restrikcióban (IUGR) }\end{array}$} \\
\hline Percentilis & $\mathrm{n}$ & $\mathrm{VI}($ mean $\pm \mathrm{SD})$ & FI $($ mean $\pm \mathrm{SD})$ & VFI (mean $\pm \mathrm{SD})$ \\
\hline$<10$ & 34 & $5,12 \pm 3,6$ & $38,4 \pm 5,4$ & $2,05 \pm 1,72$ \\
$10-25$ & 31 & $7,37 \pm 3,6$ & $39,3 \pm 5,0$ & $3,0 \pm 1,38$ \\
$26-50$ & 116 & $3,19 \pm 2,5$ & $40,7 \pm 6,4$ & $1,46 \pm 1,09$ \\
$51<$ & 73 & $4,45 \pm 1,6$ & $41,69 \pm 3,9$ & $1,89 \pm 0,9$ \\
\hline
\end{tabular}

$\mathrm{VI}=$ vascularisatiós index; FI = áramlási index; VFI = vascularisatiós áramlási index; mean = középérték; $\mathrm{SD}=$ standard deviáció 
a korábbi tanulmányok [14] eredményein túl, a jelen tanulmányban azt is vizsgáltuk, hogy milyen kapcsolat van a második és harmadik trimeszterben mért 3DPD-indexek és perinatalis kimenetel között. Megállapítottuk, hogy a 3DPD-indexek csökkenése korrelál a perinatalis szövődmények előfordulási gyakoriságának növekedésével. Más szerzők által publikált normálértékek eltérnek egymástól a mintavételi stratégia heterogenitása és az alacsony esetszám miatt, továbbá nem közölnek adatot az ultrahangkészülék adatairól, beállításairól sem. A mi eredményeink összhangban vannak de Paula és mtsai [4] és Guiot és mtsai [5] által közöltekkel, utóbbiak megállapították, hogy a placentaindexek állandóak a terhesség teljes időtartama alatt. A jelen vizsgálatban a résztvevőknél az IUGR- és a kontrollcsoport nem különbözött lényegesen egymástól az anyai életkor, terhesség, paritás, a terhesség előtti BMI vagy a vizsgálat idején betöltött terhességi hetek tekintetében. Ez a megállapítás azt jelzi, hogy ezek a tényezók nem voltak hatással a lepény angiogenesisére. A császármetszés aránya szignifikánsan magasabb volt az IUGR-rel szövődött terhességek esetén, mint a kontrollcsoportban. A növekedésben visszamaradt magzatok érzékenyen reagálnak a vajúdás alatti stresszre, ezért gyakrabban végződik a szülés sürgős császármetszéssel. A vajúdás alatt elvégzett ultrahangvizsgálat alapján megállapították, hogy az uteruskontrakciók ideje alatt a VFI és az FI szignifikánsan csökken. A kontrakció végével az értékek majdnem az azt megelőző szintre térnek vissza [15]. Az anyai BMI nemcsak az angiogenesist, hanem a mintavétel minőségét is ronthatja, ezért amennyiben a két csoport között ez eltérne, az jelentősen befolyásolná a mérési eredményeket [16]. A teljes lepényre vonatkozó 3DPD-indexek normálterhességben konstansak a terhesség 22-41. hete között. Az így számolt percentilis értékekkel [17] összevetve a kontrollcsoportban mért értékek az 50-es percentilisnek felelnek meg, a középértékek inkább az 50-es percentilis alatt helyezkednek el. Az IUGR-csoport FI-értéktartománya a 10-es percentilis alatt van, míg a másik két index a 10 es percentilis fölött található. A percentilis értékekkel való összevetésnél figyelembe kell venni, hogy a mintavételünk standardizáltan a legvascularizáltabb régióból történt, így általánosan elmondható, hogy mindhárom 3DPD-index szignifikánsan kisebb volt a normáltartományhoz képest. A VFI bizonyult a komplikációk legérzékenyebb előrejelzőjének. Azonban az FI-t javasoljuk az IUGR-terhességek kiszúrésére, mert ezt a paramétert befolyásolják legkevésbé az anyai tényezők [5]. Az FI esetén a legalacsonyabb a relatív szórás és az intraobserver/interobserver hiba, illetve legkevésbé befolyásolja a gépbeállítás a három index közül [5]. Jelen tanulmány célja az volt, hogy egy megfelelően hitelesített és reprodukálható módszert használjunk a placenta funkcionális vizsgálatára a második és harmadik trimeszterben, amely később a kockázatos terhességek gondozásába is beépíthető lehet. Az előttünk ismertetett tanulmányokban közzétett szonobiopsziás módszerek nem alkalmazhatók terhességi szürővizsgálatként, mert a mintavételi térfogat [5], a méhlepény tapadási helye és a szonobiopsziás minták száma [6] nem egységes. Egyes szerzők módszerei a teljes lepényszövet vizualizálásán $[5,6,13]$ alapszanak, ami a harmadik trimeszterben nem megvalósítható. Egységes gépbeállítással 5-15 másodpercig végeztük a mintavételt, amikor nem volt sem magzati, sem anyai mozgás.

\section{Következtetés}

Az IUGR- és kontrollcsoportba tartozó terhességek között mért különbségek a placenta véráramlására vonatkozó indexekben könnyen kimutathatók, reprodukálhatók és a megállapításuk nem függ az ultrahangkészülékek beállításaitól. Eredményeink megerősítik a csökkent lepényi vérellátás, a kedvezőtlen perinatalis kimenetel és az IUGR közötti szoros összefüggést [18, 19]. Javasoljuk a Mercé-féle placenta-szonobiopszia [7] használatát az IUGR-terhességek szûrése céljából, hogy a perinatalis kimenetel kedvezőbbé válhasson. A térfogati egységek beolvasása után a felvétel továbbítható szakértőknek, így a magas kockázatú terhességek nyomon követése szélesebb körben megvalósulhat. Mindazonáltal hangsúlyozni kell, hogy a terápiás következtetés levonásához a teljes klinikai háttér ismerete szükséges.

Anyagi támogatás: Jelen tanulmány elkészültét a Délalföldi Reprodukciós Egészség 2000 Alapítvány támogatta.

Szerzői munkamegosztás: M. A., S. A., J. M., N. G.: A hipotézisek kidolgozása. S. A., M. A.: A vizsgálatok lefolytatása. Ny. T.: A statisztikai adatok elemzése. M. A., J. M.: A kézirat megszövegezése. S. A., N. G.: A kézirat javítása. A cikk végleges változatát valamennyi szerző elolvasta és jóváhagyta.

Érdekeltségek: A szerzőknek nincsenek érdekeltségeik.

\section{Irodalom}

[1] de Onis M, Garza C, Onyango AW, et al. WHO growth standards for infants and young children. Arch Pediatr. 2009; 16: $47-53$.

[2] Lausman A, McCarthy FP, Walker M, et al. Screening, diagnosis, and management of intrauterine growth restriction. J Obstet Gynaecol Can. 2012; 34: 17-28.

[3] Gaudineau A. Prevalence, risk factors, maternal and fetal morbidity and mortality of intrauterine growth restriction and small-forgestational age. J Gynecol Obstet Biol Reprod. (Paris) 2013; 42: 895-910.

[4] de Paula CF, Ruano R, Campos JA, et al. Quantitative analysis of placental vasculature by three-dimensional power Doppler ultrasonography in normal pregnancies from 12 to 40 weeks of gestation. Placenta 2009; 30: 142-148.

[5] Guiot C, Gaglioti P, Oberto M, et al. Is three-dimensional power Doppler ultrasound useful in the assessment of placental per- 
fusion in normal and growth-restricted pregnancies? Ultrasound Obstet Gynecol. 2008; 31: 171-176.

[6] Noguchi J, Hata K, Tamaka H, et al. Placental vascular sonobiopsy using three-dimensional power Doppler ultrasound in normal and growth restricted fetuses. Placenta 2009; 30: 391-397.

[7] Mercé LT, Barco MJ, Bau S. Reproducibility of the study of placental vascularization by three-dimensional power Doppler. J Perinat Med. 2004; 32: 228-233.

[8] Tuuli MG, Houser M, Odibo L, et al. Validation of placental vascular sonobiopsy for obtaining representative placental vascular indices by three-dimensional power Doppler ultrasonography. Placenta 2010; 31: 192-196.

[9] Guimarães Filho HA, Araujo Junior E, Mattar R, et al. Placental blood flow measured by three-dimensional power Doppler ultrasound at 26 to 35 weeks gestation in normal pregnancies. J Matern Fetal Neonatal Med. 2010; 23: 69-73.

[10] Sankaran S, Kyle PM. Aetiology and pathogenesis of IUGR. Best Pract Res Clin Obstet Gynaecol. 2009; 23: 765-677.

[11] Surányi A, Kozinszky Z, Molnár A, et al. Placental three-dimensional power Doppler indices in mid-pregnancy and late pregnancy complicated by gestational diabetes mellitus. Prenat Diagn. 2013; 33: 952-958.

[12] Hadlock FP, Harrist RB, Sharman RS, et al. Estimation of fetal weight with the use of head, body and femur measurements: a prospective study. Am J Obstet Gynecol. 1985; 151: 333-337.

[13] Hata T, Tanaka H, Noguchi J, et al. Three-dimensional ultrasound evaluation of the placenta. Placenta 2011; 32: 105-115.

[14] Pomorski M, Zimmer M, Florjanski J, et al. Comparative analysis of placental vasculature and placental volume in normal and
IUGR pregnancies with the use of three-dimensional Power Doppler. Arch Gynecol Obstet. 2012; 285: 331-337.

[15] Sato M, Noguchi J, Mashima M, et al. 3D power Doppler ultrasound assessment of placental perfusion during uterine contraction in labor. Placenta 2016; 45: 32-36

[16] Eastwood KA, Patterson C, Hunter AJ, et al. Evaluation of the predictive value of placental vascularisation indices derived from 3-dimensional power Doppler whole placental volume scanning for prediction of pre-eclampsia: A systematic review and metaanalysis. Placenta 2017; 51: 89-97.

[17] Pomorski M, Zimmer M, Fuchs T, et al. Quantitative assessment of placental vasculature and placental volume in normal pregnancies with the use of 3D power Doppler. Advin Med Sci. 2014; 59: 23-27.

[18] Molnár A, Surányi A, Nyári T, et al. Examination of placental three-dimensional power Doppler indices and perinatal outcome in pregnancies complicated by intrauterine growth restriction. Int J Gynaecol Obstet. 2015; 129: 5-8.

[19] Jakó M, Surányi A, Kaiser L, et al. Pathophysiological changes of umbilical vessels in intrauterine growth restriction. [A köldökzsinór érrendellenességei az intrauterin fejlődési visszamaradásban.] Orv Hetil. 2014; 155: 1989-1995. [Hungarian]

(Surányi Andrea dr., Szeged, Semmelweis u. 1., 6725 e-mail: gaspar-suranyi.andrea@med.u-szeged.hu)

\title{
HIR DETMÉ NY
}

\author{
A Magyar Pathologusok Társasága és \\ a Magyar Onkológusok Társasága \\ által a 2016. évre meghirdetett
}
"Immunológiai folyamatok szerepe a daganatok progressziójában és terápiájában" címü

KROMPECHER ÖDÖN-pályázat nyertesei:

\section{I. helyezést ért el:}

„Palingenia longicauda” jeligével Fésüs Viktória, a SE ÁOK V. évfolyamos hallgatója

\section{II. helyezett:}

„Hello Kidney” jeligével Pósfai Boglárka, a SZTE ÁOK VI. évfolyamos hallgatója

Budapest, 2017. március 24.

\author{
Magyar Pathologusok Társasága \\ és \\ Magyar Onkológusok Társasága \\ vezetösége
}

